Klaudia KAŁĄŻNA, Remigiusz RoSICKI

Uniwersytet im. Adama Mickiewicza, Poznań

\title{
Czarnogóra i Bośnia-Hercegowina (problemy graniczne i etniczne)
}

\begin{abstract}
bszar Europy Południowo-Wschodniej stał się miejscem, gdzie w latach 90. ponownie wybuchła beczka prochu ${ }^{1}$. Ostry konflikt narodowościowy spowodowany był specyfiką tego obszaru. Bałkany (obszar Jugosławii) to tygiel narodowościowy, religijny i kulturowy. Do ponownego jego rozpalenia wystarczył rozkład jugosłowiańskiego państwa socjalistycznego i duszone przez wspólną socjalistyczną ideologię animozje między różnymi grupami. Polityka Tito oparta na haśle braterskiej wspólnoty (bratstva jedinstva) zaczęła zanikać wraz z jego śmiercią. Obecny obraz Bałkan jest próbą pogodzenia konfliktów, które trawiły tą ziemię przez poprzednie wieki - większość z nich nie jest rozwiązana do dzisiaj (np. Kosowo) ${ }^{2}$. Współczesna granica między Czarnogórą i Bośnią-Hercegowinąjest wyrazem wielokulturowości i determinującej ją geografii tego obszaru. Granice wszystkich państw byłej Socjalistycznej Federacyjnej Republiki Jugosławii (Socijalistièka Federativna Republika Jugoslavija) ${ }^{3}$ to rezultat rywalizacji zbrojnej, co stanowi dowód, że kategoria siły jest dalej doniosłym narzędziem do analizy stosunków międzynarodowych (w tym procesu kształtowania się granic).
\end{abstract}

\section{Historia i formulowanie granic}

Istotne zręby państwowości Czarnogóry należy wiązać z napływem plemion słowiańskich na terytorium Europy Południowo-Wschodniej.

1 Podobne wydarzenia miały miejsce przed wybuchem I wojny światowej i w XIX wieku nazywanym wiekiem rodzącym nowe narody.

2 Serbia and Montenegro, UNHCER Global Apeal 2005, s. 282-287; A. Zhelyazkova, Ethnic Minorities in Ex-Yugoslavia, "Transantlantic Internationale Politik" 2002, no. 3, s. 61-66.

3 Nazwa państwa funkcjonująca w okresie 1963 do 1992. 
Czarnogóra od XII wieku wchodzi w skład państwa serbskiego. W wiekach X-XII funkcjonuje królestwo Zeta, które stanie się podstawą dla tradycji, do której będą się odwoływać Czarnogórcy, uzasadniając swoje zręby państwowości i odrębności. Pod koniec XV wieku Czarnogóra została podbita przez Turków Otomańskich. Turcy nie podbili jedynie niewielkich terenów górzystych. Tereny te zamieszkiwali mnisi, którzy następnie tworzą autonomiczne państwo o charakterze teokratycznym. Przełom XVIII i XIX wieku to umocnienie państwowości - dzięki uznaniu państwowości przez Turcję i powiększeniu terytorium. W 1852 roku państwo przyjmuje postać świecką, a osiem lat później uzyskuje niepodległość ${ }^{4}$. W XIX wieku następuje znaczący rozwój kulturalny tego kraju (język, literatura itd.). Trzeba zaznaczyć, że wiek XIX dla całej Europy Środkowej i Południowo-Wschodniej przyniósł ożywienie narodowe i kulturalne. W 1855 r. uchwalono I ustawę zasadniczą Czarnogóry. W 1878 roku dołączono do tego państwa część obszaru tzw. Wielkiej Bułgarii. W latach 1912-1913 miał miejsce konflikt między Grecją, Bułgarią i Serbią a Turcją. Czarnogóra opowiada się przeciwko Turcji. Nagrodą za to jest kolejne powiększenie terytorium. Po I wojnie światowej Czarnogóra wchodzi w skład Królestwa Serbów, Chorwatów i Słoweńców (SHS). W 1919 roku wybucha powstanie niepodległościowe, które kończy się porażką. W 1929 roku Królestwo SHS przekształca się w Królestwo Jugosławii - Czarnogóra zostaje włączona do prowincji Zeta. W okresie II wojny światowej Czarnogóra była pod okupacją Włochów, następnie Niemców. W 1949 roku państwo to wchodzi w skład Federacyjnej Republiki Jugosławii. W 1992 roku odbywa się referendum - wynik: prawie $96 \%$ głosujących jest za pozostaniem w związku z Serbią. Czarnogóra staje się związkową Republiką Jugosławii. Ostatecznie w 2006 odbywa się referendum - wynik: większość opowiada się za niepodległością ${ }^{5}$. Należy zwrócić uwagę na obostrzenia referendum, które w gruncie rzeczy narzuciła Unia Europejska - tzn. referendum miało być ważne, jeżeli

${ }^{4}$ N. Davies, Europa, Wyd. ZNAK, Kraków 2001, s. 886-887.

5 N. Miller, Sebia and Montenegro, w: Eastern Europe. An Introduction to the People, Lands, and Culture. Volume III, Santa Barbara-Denver-Oxford 2005, s. 529-581; J. D. Treadway, Montenegro (History), w: R. Frucht (ed.), Encyklopedia of Eastern Europe. From the Congress of Vienna to the Fall of Communism, Garland Publishing, New York-London 2000, s. 507-509, K. Szilágyi (Rev. F. Pece, S. Babic), Good Neighbors or Bad Neighbors? Hungarians and Serbs during the centuries, Budapest 1999, s. 7 i n. 
wzięło by w nim udział co najmniej 50\% uprawnionych do głosowania obywateli, a poparcie niepodległości wyniosłoby $55 \%$. Takie wysokie progi zaproponowane były przez J. Solanę, co w gruncie rzeczy było wynikiem sceptycznego stanowiska do wspierania niepodległości tego kraju, mogłoby to się stać niewygodnym przypadkiem, na który powoływałyby się inne podmioty dążące do niezależności (Kosowo, Republika Serbska, Wojewodina $)^{6}$. Referendum odbyło się 21 maja 2006 roku - 55,5\% mieszkańców opowiedziało się za utworzeniem niepodległego państwa, a frekwencja wyniosła $86,3 \%{ }^{7}$. Obecnie Czarnogóra jest najnowszym członkiem Organizacji Narodów Zjednoczonych, jako nowy podmiot prawa międzynarodowego. Wcześniej swą niezależność i dążenie do niepodległości wykazywała na różne sposoby - takim symbolicznym przykładem jest wprowadzenie euro na swoim terenie w 2002 roku.

Początki Bośni-Hercegowiny również należy wiązać z napływem Słowian. Nazwa Bośnia pochodzi od nazwy rzeki, która płynie przez Sarajewo. Natomiast nazwa Hercegowina pochodzi od Stefana Vukčića, który mianował się księciem tego terenu (książę = herzog) - Hercegowina ukształtowała się w XIV wieku. W średniowieczu Bośnia-Hercegowina zależna była od Bizancjum, Serbii i Węgier. W 1908 roku Austria anektuje Bośnię-Hercegowinę. W odwecie zamachowcy zabijają następcę tronu austriackiego w 1914 roku. A to uruchomiło całą maszynerię dyplomatyczną i przede wszystkim militarną Europy, czego skutkiem była I wojna światowa. W 1918 roku obszar ten staje się składową Królestwa SHS, a w roku 1929 częścią Jugosławii. W okresie II wojny światowej powstało niezależne państwo Hercegowina. W 1946 roku wprowadzona zostaje nowa konstytucja republiki Jugosławii, na mocy której Bośnia i Hercegowina stała się jedną z 6 republik socjalistycznych wchodzących w skład nowego państwa. Ostatecznie w 1995 roku powstaje państwo Bośnia-Hercegowina - złożone z dwóch bytów Federacji Bośni i Hercegowiny oraz Republiki Serbskiej ${ }^{8}$.

6 M. Zawadzki, Czarnogóra decyduje czy zerwać z Serbia, „Gazeta Wyborcza” z 20.05.2006 r. (http://www.gazeta wyborcza.pl/dziennikarze/1,84008,3357268.html, 6.04.2008, a.m 3.00).

7 Zob.: Republička komisija za sprovođenje referenduma o državnom statusu Republike Crne Gore, http://www.rrk.cg.yu/ 12.09.2007, a.m. 3; Action plan for functioning of the Republic of Montenegro as an independent state, 2006, s 1-3; Declaration on Relations with the Republic of Serbia after gaining Independence, 2006, s. 1-2.

8 J. M. B. Lyon, Bosnia-Hercegovina, Birth of the Republi of (1992), w: R. Frucht (ed.), Encyklopedia of Eastern Europe. From the Congress of Vienna to the Fall of 


\section{Naturalne fragmenty granic}

Granica między Czarnogórą a Bośnią-Hercegowiną wynosi 225 km. Obszary te były pewną linią wpływów muzułmańskich w tej części Europy. Przykładowo zróżnicowanie etniczne i religijne Bośni-Hercegowiny jest tego obrazem. Po pierwsze granice determinowane są przez zróżnicowanie etniczne i religijne, po drugie przez czynniki geograficzne - np. góry. Ostatecznie współczesny obraz granic jest wynikiem uzgodnień politycznych. Większość granicy Bośni-Hercegowiny na wschodzie kraju jest uzgodniona i nie budzi sprzeciwu sąsiadów. Natomiast problemy dotyczą niektórych części wzdłuż rzeki Drina ${ }^{9}$. Na granicy z Czarnogórą jest wiele możliwości wyznaczania granicy zgodnie z naturalnymi punktami.

\section{Administracja i polityczna struktura}

Państwo Bośnia i Hercegowina to dwa organizmy - pierwszy organizm to Federacja Bośni i Hercegowiny a drugi to Republika Serbska (nie mylić z Serbią). Oprócz tych podmiotów na obszarze państwa Bośnia-Hercegowina znajduje się dystrykt Brčko (pod kontrolą międzynarodową). Federacja Bośni i Hercegowiny to dwie duże krainy - Alpy Dynarskie (Bośnia - zajmuje ok. 2/3 kraju) i Nizina Panońska (Hercegowina - zajmuje ok. 1/3 kraju). Wschodnią granicę Bośni-Hercegowiny formuje Republika Serbska, która graniczy z Serbią i Czarnogórą. Państwo Czarnogóra zostało powołane, jako nowy podmiot prawa międzynarodowego w 2006 roku w wyniku referendum. Powołanie nowego podmiotu prawa międzynarodowego wytworzyło nową sytuację w regionie i konieczność stabilizacji stosunków społecznych, politycznych (w tym granicznych) między Czarnogórą i jej sąsiadami (w tym z Bośnią-Hercegowina). Wcześniej granice między Bośnią-Hercegowiną a Jugosławią (teraz niepodległa Czarnogóra oraz Serbia) wyznaczało Porozumienie

Communism, Garland Publishing, New York-London 2000, s. 78-79; T. Poulsen, Bosnia-Hercegovina, w: R. Frucht (ed.), Encyklopedia of Eastern Europe. From the Congress of Vienna to the Fall of Communism, Garland Publishing, New York-London 2000, s. 77-78.

9 https://www.cia.gov/library/publications/the-world-factbook/geos/bk.html\#Issues, 17.09.2007, p.m. 8.45. 
z Dayton $^{10}$. Wyznaczenie granic na wschodniej granicy bośniacko-hercegowińskiej ułatwione było dzięki znacznej diasporze serbskiej w tym kraju (istnienie w ramach B\&H Republiki Serbskiej) $^{11}$. Natomiast w 2008 roku doszło do dwustronnych rozmów między Czarnogórą i Chorwacją podczas których ustalono protokół rozbieżności, co do granicy na Adriatyku - spór dotyczy fragmentu Zatoki Kotorskiej. Sporne kwestie zawarte w protokole rozpatrzyć ma Międzynarodowy Trybunał Sprawiedliwości w Hadze.

Federacja Bośnia-Hercegowina składa się z 10 kantonów (74 gminy) - tylko jeden z nich graniczy z Czarnogórą. Ważniejsze dla tematu jest określenie obszaru Republiki Serbskiej. Republika Serbska składa się z siedmiu regionów (63 gmin). Trzy regiony Republiki Serbskiej tworzy granicę z Czarnogórą - Trebinie, Foča i Vleciniča. Natomiast obszar Czarnogóry podzielony jest administracyjnie na 21 regionów. Z trzema regionami Republiki Serbskiej sąsiaduje sześć regionów czarnogórskich (Herceg Novi, Kotor, Nikšić, Plužine, Žabljak, Pljevlja) ${ }^{12}$.

\section{Struktura etniczna i religijna}

Specyficzne relacje na granicy między Bośnią-Hercegowiną a Czarnogórą wynikają z różnorodnej struktury etnicznej i religijnej. Przykładowo północna część Republiki Serbskiej (północno-zachodnia część Bośni-Hercegowiny) zamieszkana jest w większości przez bośniackich muzułmanów, natomiast południowo-zachodnia część Republiki Serbskiej (w tym Bośni-Hercegowiny) zamieszkiwana jest przez Serbów. Znaczna diaspora Serbów zamieszkuje dużą część Hercog Novi - przygranicznego regionu w Czarnogórze. Większość pasa przygranicznego po stronie czarnogórskiej zajmują Czarnogórcy (z wyjątkiem wspomnianego Hercog Novi). Ludność, która określa się Serbami (mieszkająca w Bośni-Hercegowinie) czuje się bardziej związana z samą Serbią. Czarnogóra formalnie do 2006 roku była częścią Serbii. Oderwanie tego fragmentu od obszaru, z którym politycznie i społecznie się identyfikowali nie sprzyja poprawności stosunków

10 Tekst porozumienia: http://www.ohr.int/dpa/default.asp?content_id=380, 5.04.2008, p.m. 4.00 .

11 Bosnia \& Herzegovina and Montenegro, w: Cross-Border Co-operation in the Balkan - Danube Area. An analysis of Strengths, Weaknesses, Oppoportunities and Threats, Council of Europe, I.S.I.G., s. 73-74.

$12 \mathrm{http} / / / \mathrm{www} \cdot$ montenegro.yu. 
między nimi. Ale trzeba zwrócić uwagę, że jest jeden czynnik, który wpływa na możliwość poprawnej komunikacji. Jest nim religia. Na południowej części granicy z Czarnogóra, żyją Serbowie, którzy są wyznania prawosławnego - tak samo jak ponad 70\% Czarnogórców. Te populacje znajdują wspólny język w krytyce ludności bośniackiej dominującej w północnej części granicy z Czarnogórą. Przykładem jest wspólna obawa przed stawianiem przez Bośniaków nowych budowli sakralnych - przeważnie są to meczety sponsorowane przez kraje muzułmańskie. Populacja bośniacka Bośni-Hercegowiny opiera się na innej identyfikacji. W połowie lat 90. większość Bośniaków (B\&H) opowiedziała się za określeniem siebie jako Bośniaków - Muzułmanów. Diaspora w Republice Serbii (teraz i w Czarnogórze) jest temu przeciwna - ale nie odcina się od korzeni religijnych ${ }^{13}$.

Zamieszkiwanie obok siebie (w Bośni-Hercegowinie) narodowości bośniackiej i serbskiej stało się w latach 90' przyczyną drastycznych konfliktów zbrojnych, jak i wpłynęło na obecny podział administracyjny i polityczny Bośni-Hercegowiny. Struktura narodowościowa Bośni-Hercegowiny jest następująca: Bośniacy/Muzułmanie - 40\%, Serbowie - 32\%, Chorwaci $-18 \%{ }^{14}$. Obecnie struktura narodowościowa Czarnogóry jest następująca: Czarnogórcy - 43,16\%, Serbowie - 31,99\%, Bośniacy - 7,77\%, Albańczycy -5,03\%, Bośniacy/Muzułmanie-3,97\%, Chorwaci-1,10\%, Romowie $-0,46 \%$, inni $-6,29 \%{ }^{15}$. Obecnie wzajemne różnice (religijne, kulturowe itd.) podgrzewane są przeważnie w okresie kampanii politycznych. Ma to miejsce również w kampaniach wyborczych na szczeblu lokalnym, gdzie łatwiej wykorzystywać wzajemne animozje ${ }^{16}$.

Na strukturę narodowościową nakłada się również struktura religijna. Procentowy udział określonych religii w Bośni-Hercegowinie jest nastę-

13 G. Bašić, Political and legal status of national minorities in Serbia and Montenegro, w: Prospects of Multiculturality in Western Balkan States, http://www.fes.org.mk/pdf/GORAN\%20BASIC\%20\%20 POLITICAL\%20AND\%20LEGAL $\% 20$ STA,TUS $\% 20$ OF\%20NATIONAL $\% 20$ MINORITIES $\% 20$ IN $\% 20$ SERBIA\%20AND\%20MONTE\%20NEGRO.pdf, 14.09.2007, a.m. 3.

14 T. M. Poulsen, Bosnia-Hercegovina, w: R. Frucht (ed.), Encyklopedia of Eastern Europe. From the Congress of Vienna to the Fall of Communism, Garland Publishing, New York-London 2000, s. 77.

15 http://www.fes.org.yu/scg/archive.asp, 14.09.2007, a.m. 3; Saopštenje br. 295 (Statement No. 295), Republicki zavod za statistiku (Republican Statistics Office), Beograd 2003.

${ }_{16}$ Republic of Montenegro. Parliamentary Election 10 september 2006, OSCE/ODIHR Election Observation Mission Final Report, Warsaw 2006, s. 16. 
pujący: 40\% - muzułmanie, 31\% - prawosławni, 15\% - katolicy, 14\% - inne wyznania. W Czarnogórze struktura religijna jest następująca: $74,24 \%$ - prawosławni, $17,74 \%$ - Sunnici, 3,54\% - katolicy ${ }^{17}$. W Czarnogórze dominującą religijną pozycję mają prawosławni - część z nich podlega Serbskiemu Kościołowi Ortodoksyjnemu, a inni Czarnogórskiemu Kościołowi Ortodoksyjnemu. Co wpływa na relacje Czarnogórców (także mniejszości Serbskiej) na relacje z innymi grupami religijnymi ${ }^{18}$. Mimo wspólnego nurtu religijnego widoczne są sprzeczności między tymi kościołami. O ile Kościół Czarnogórski działa w celu pogodzenia wielokulturowości, o tyle Kościół Serbski odcina się od kontaktów z Muzułmanami (Bośniakami), co widoczne jest też w relacjach przygranicznych.

\section{Języki}

W Czarnogórze (jak w wielu państwach postjugosłowiańskich) stosowany jest język serbsko-chorwacki (tutaj widoczne są spory, co do nazwy i istnienia wspólnych standardów). W XX wieku język ten na terenie Socjalistycznej Federacyjnej Republiki Jugosławii przeżywał dwa odrębne procesy $-\mathrm{z}$ jednej strony odgórnej unifikacji, a w latach 80 ' - w sumie - dezintegracji. Największe znaczenie ma dialekt sztokawki (štokawski). Dialekt ten jest bazą dla trzech języków - serbskiego, chorwackiego i bośniackiego. Wspólna baza językowa ułatwia wzajemną komunikację. Język nie stanowi znaczącej bariery w relacjach przygranicznych. Dialektem sztokawskim mówi się w Serbii, Bośni, Czarnogórze i dużej części Chorwacji. Dialekt sztokawski posiada swoje odmiany ${ }^{19}$.

W Czarnogórze języki mniejszości są używane na sesjach władz lokalnych, w dokumentach państwowych i innych oficjalnych dokumentach, w procedurze sądowej i administracyjnej, także w wyborach ${ }^{20}$. Nie zaw-

17 Report on Human and Minority. Right and Judicary Reform in Montenegro, CEDEM, CHMR, FOSIRGM 2007, s. 41; http://www.monstat.cg.yu.

${ }_{18}$ Report on Human Minority. Right and Judicary Reform in Montenegro, CEDEM, CHMR, FOSIRGM 2007, s. 9.

${ }_{19}$ Odmianą dialektu sztokawskiego są: ekawski, jekawski i ikawski. Ekawski używany jest w całej Serbii i wschodniej Chorwacji. Jekawskim mówi się w Chorwacji, Bośni, Czarnogórze i zachodniej Serbii. Ikawskim mówi się w Chorwacji i zachodniej Bośni-Hercegowinie.

${ }^{20}$ Miniorities in Montenegro Legislation and Practice, Swedish Helsinki Committee, YIHR 2007, s. 17; http//www.yihr.or. 
sze zapisy prawne w zakresie stosowania języków mniejszości np. we władzach lokalnych są rzeczywiście realizowane. W praktyce widoczne są utrudnienia w realizacji dostępu uczniów do nauki w języku mniejszości z jakiej się wywodzą. Wynika to przeważnie ze złej infrastruktury szkolnej, znacznych kosztów i innych problemów logistycznych ${ }^{21}$. Natomiast w Bośni formalnie funkcjonują 3 języki urzędowe - chorwacki, serbski, bośniacki. Możliwość porozumiewania między „różnymi” językami i dialektami ułatwia wzajemną komunikację. Język nie stanowi, więc takiej bariery w relacjach między zwykłymi ludźmi, którzy żyją na granicy, tak jak np. na granicy polsko-niemieckiej. Widoczne są natomiast tendencje autonomizacji języka chorwackiego, w zasadzie można mówić, że język ten wyodrębnił się z rodziny języków serbsko-chorwackich, m.in. przy wsparciu politycznym, co widoczne jest w przeprowadzanych jego reformach.

\section{Turystyka, jako najważniejsza część ekonomii}

Najważniejszą częścią gospodarki tego regionu jest turystyka. Widać to na podstawie zwiększonego ruchu granicznego (między Czarnogóra, Chorwacją i B\&H). Z punktu widzenia atrakcyjności największe znaczenie mają obszary położone najbliżej wybrzeża. W przypadku Czarnogóry będą to regiony Hercog - novi, Kotor i Tivat. Ze strony B\&S Trebinje i Herzegovina - Neretva (ten region jako jedyny ma dostęp do morza w B\&H). Znaczenie tych regionów zwiększa wspólna granica z Chorwacją. Obszar ten jest też ważny ze względu na trasę wzdłuż wybrzeża w kierunku Albanii i Grecji. Jadąc z Chorwacji lub Bośni-Hercegowiny obierany jest kierunek do Tivan, Kotor (port). Następnie albo na Bar (port - terminal) i Ulcinj, albo Podgorica, Tuzi i Shkoder (pierwsza trasa prowadzi przez obszar na północ od Jeziora Skadar, a druga na południe).

Współpraca w tym obszarze granicznym jest szczególna ze względu na dochody z turystyki. Dla przykładu (w Czarnogórze) podróże i przemysł turystyczny wytwarzają 17\% dochodu krajowego brutto (GDP), podróże i turystyka 13,5\% GDP a w turystyce pracuje ok. 10\% zatrudnionych ${ }^{22}$.

21 Miniorities in Montenegro Legislation and Practice, Swedish Helsinki Committee, YIHR 2007, s. 20-24.

22 Montenegro Travel and Tourism: Unlocking the Potential for Growth, World Travel and Tourism Council 2007, s. 12-13. 


\section{Infrastruktura}

Infrastruktura komunikacyjna Czarnogóry przedstawia się następująco: długość wszystkich dróg wynosi 7368 km, długość dróg utwardzonych $4742 \mathrm{~km}$, a nieutwardzonych $2626 \mathrm{~km}$. Natomiast długość szlaków kolejowych wynosi $250 \mathrm{~km}$ (więc nie jest imponująca). Ilość dóbr przewożonych transportem kolejowym wynosi ok. $4 \mathrm{mln}$ ton. Drogi w Czarnogórze nie są oceniane zbyt pozytywnie. Wynika to z zawiłej współczesnej historii, jak i specyfiki terenów górskich. Czarnogóra posiada trzy porty - Bar (także terminal), Zelenika, Kotor (ładowność 5 mln ton), także trzy porty lotnicze z pasami startowymi - Podgorica, Tivat, Berane (dwa kolejne lotniska nie posiadają pasów startowych, tzn. nie są utwardzone) ${ }^{23}$. Czarnogóra posiada także flotę handlową - 4 statki o ładowności 1000 GRT.

Natomiast infrastruktura transportowa Bośni-Hercegowiny jest następująca: długość linii kolejowych wynosi 608 km, długość dróg 21846 km (utwardzone - $11425 \mathrm{~km}$ i nieutwardzone $10421 \mathrm{~km}$ ), Bośnia-Hercegowina posiada żeglugę wewnętrzną - Sava River (to jest północna granica państwa). Ponadto funkcjonują porty i terminale: Bosanski Brod, Bosanska Gradiska i Brčko. Są to porty wewnętrzne na rzece Sava. Port, który nie jest związany $\mathrm{z}$ rzeką to Orasje ${ }^{24}$.

\section{Etniczne relacje na obszarze granicznym - Kosowo, jako czynnik destabilizujący}

Obszar Południowo-Wschodniej Europy zrodził wiele nacjonalistycznych koncepcji terytorialnych. Na przykład: Wielka Serbia, Wielka Albania, Wielka Bułgaria itp. Koncepcje te zderzyły się z rzeczywistością - konfliktami etnicznymi, religijnymi, politycznymi, jak i okolicznościami historycznymi. Pozostałością narodowych koncepcji jest spuścizna Wielkiej Serbii i Wielkiej Albanii. Efektem tego jest wciąż nieuregulowana sprawa Kosowa. Ponad 40\% populacji Kosowa to Albańczycy. Kosowo w pewnym okresie posiadało autonomię w ramach Serbii. Podczas rządów S. Miloševicia autonomia została zniesiona. W 1999 r. pod naci-

$23 \mathrm{https} / /$ www.cia.gov/library/publications/the-world-factbook/geos/mj.html\#Comm, 10.11.2008, a.m. 8.00.

$24 \mathrm{https} / / /$ www.cia.gov/library/publications/the-world-factbook/geos/bk.html\#Trans, 17.09.2007, p.m. 8.40. 
skiem międzynarodowej opinii publicznej NATO dokonało bombardowań Jugosławii. Pretekstem były potencjalne zbrodnie na mniejszości albańskiej. Dokonując nalotów NATO złamało konwencje wojenne o niszczeniu celów cywilnych. W 1999 r. powołano misję tymczasową ONZ - United Nations Interim Administration in Kosovo ${ }^{25}$. Obszar Kosowa jest protektoratem ONZ, ale formalnie należy do Serbii. Według prawa serbskiego Kosowo jest autonomiczną prowincją - Kosowo i Metohija. Serbskich interesów terytorialnych broni Rosja - podobnie jak w XIX wieku.

Kosowo to obszar leżący w południowej części Serbii. Obszar ten graniczy z: Albanią (południe), Czarnogórą (zachód), Macedonią (południe). W zasadzie Kosowo to dwie krainy - Kosowo i Metohija. Nazwa Metohija pochodzi od nazwy - własność kościoła. Obszar ten był własnością prawosławnego kościoła (lenno). Ludność albańska nazywa ten obszar Rrafshi i Dukagjinit. Granicę między Kosowem i Metohiją tworzy rzeka Drenica. Historycy nie są jednomyślni w zakresie genezy etnicznej obszarów Kosowa, także Albanii. W XI wieku tereny te rządzone były przez Bułgarów. W kolejnych wiekach Kosowo rządzone było przez Bizancjum. W XII wieku Serbowie podbili obszar Kosowa i Albanii. Dynastia Nemanjiciów rozpowszechniła silnie religię prawosławną. Stąd też duża kumulacja klasztorów na obszarze Kosowa. W okresie średniowiecza większość stanowili Słowianie i zarazem chrześcijanie. Panowanie Turków zaczęło się od XV wieku do początku XX wieku. Na obszarze tym zaczęły dominować: kultura islamu i język turecki. W 1689 roku na tereny Serbii i Albanii wtargnęło wojsko austriackie. Był to jeden z pierwszych większych konfliktów. Część mieszkańców Albanii i Serbii stanęła po stronie Austrii, inna część po stronie Turków. Wielka siła turecka zmusiła do ucieczki wielu Serbów i hierarchię kościoła prawosławnego. Wyżej wymienione przykłady to tylko zarys mieszania się religii i narodowości na tych terenach. W 1912 roku (dzięki uzgodnieniom międzynarodowym) Kosowo stało się częścią Serbii, a północny obszar Metohija przyłączone zostało do Czarnogóry.

Konflikty polityczne widoczne były po uzyskaniu autonomii przez Kosowo w ramach Serbii. Albańczycy w Kosowie współpracowali z Albanią, a Serbowie współpracowali z Serbią. Przykładem współpracy Al-

25 K. A. Mingst, Essentials of international relations, W. W. Norton \& Company 2004; polskie wydanie: K. A. Mingst, Podstawy stosunków międzynarodowych, PWN, Warszawa 2006, s. 216-217. 
bańczyków z Tiraną było wprowadzenie albańskiego systemu edukacji w Kosowie (lata 70'). Tendencje bliższych relacji zatrzymane były przez strach przed stalinowskim systemem w Albanii.

Obecnie ludność albańska znajduje się na obszarze Kosowa, Macedonii, Czarnogóry i oczywiście Albanii. W krajach przygranicznych jest to traktowane jako zagrożenie. Przykładowo, przyznanie niepodległości Kosowu może zacząć podobne roszczenia na obszarach - Czarnogóry i Macedonii. Widać jest to szczególnie na granicy z Macedonią, gdzie szybko zmienia się struktura etniczna - w znacznym tempie rośnie populacja albańska. Z drugiej strony powstanie niepodległego Kosowa mogłoby spowodować odpływ z Macedonii ludności albańskiej. Należy dodać, że populacja albańska na obszarze Macedonii to 23\% - większość przy granicy $^{26}$. Brak asymilacji mniejszości albańskiej widoczny jest na znacznych obszarach granicznych Kosowa, acz nie należy dokonywać całkowitej generalizacji. Przykładem może być ambiwalentna postawa Albańczyków zamieszkujących Czarnogórę, którzy mimo silnych związków z Albanią i Kosowem podkreślają swoją odrębność. Z silnej państwowości populacji albańskiej nie jest zadowolona Grecja. Wynika to z konfliktu z ludnością albańską, która (po II wojnie światowej) została wygnana z greckiego Epiru.

Oprócz konfliktów etnicznych występują konflikty religijne: Serbowie, Czarnogórcy i Macedończycy to w większości prawosławni. Natomiast Albańczycy to muzułmanie. Sytuacji nie ułatwiają różnice językowe - Serbowie (serbsko-chorwacki, dialekt sztokawski, ekawski), Albańczycy (albański), Macedończycy (70\% - macedoński), Czarnogórcy (serbsko-chorwacki, dialekt sztokawski, jekawski).

Obszar ten też stanowi wyzwanie dla bezpieczeństwa. Przykładowo, przestępczość i energetyka. W pierwszym wypadku przez kraje te przebiega szlak narkotykowy - w większości przypadków jest to opium. Wcześniej był to ważny obszar przemytu broni. W znacznej mierze przemyt narkotykowy opanowany jest przez Albańczyków. Albańczykom łatwiej jest nawiązywać kontakty z pośrednikami Tureckimi. Raporty Interpolu mówiły także o finansowaniu rebelii albańskiej w Kosowie (1999) z pieniędzy, które pochodziły z handlu narkotykami. Natomiast w drugim

26 A. Panev, Macedonia, w: R. Frucht (ed.), Eastern Europe. An Introduction to the People, Lands, and Culture, vol. 3, 2005, s. 608-609; R. Austin, Albania, w: R. Frucht (ed.), Eastern Europe. An Introduction to the People, Lands, and Culture, vol. 3, 2005, s. 726 . 
wypadku należy spodziewać się inwestycji w rurociagi (inwestycje rosyjskie, m.in. Blue Stream II).

Na obszarze panuje dziwna sytuacja administracyjna. Przykładowo: paszporty są wydawane przez administrację UNMIK - ONZ, podobnie jest z innymi dokumentami (dowody osobiste, dowody rejestracyjne pojazdów). UNMIK stworzył multikulturową policję. W funkcjonującym Zgromadzeniu Narodowym zagwarantowano 10 miejsc Serbom i kolejne 10 miejsc innym mniejszościom (kolejnych 100 członków wybiera się w wyborach).

Podsumowując stosunki graniczne między Kosowem a innymi państwami (Czarnogórą, Macedonią, Serbią) nie należą do poprawnych. Powstanie państwa z populacją albańską uznane zostałoby za spełnienie marzeń albańskich politycznych ideologów. Państwo takie istniało w okresie II wojny światowej. Marionetkowy twór stworzyli Włosi, którzy oddali Albańczykom pod rządy - część Macedonii, Kosowo i inne podbite obszary. Ambicje polityczne, konflikty religijne i etniczne to trzy główne czynniki, które destabilizują ten obszar.

17 lutego 2008 roku Kosowo proklamowało niepodległość, co spotkało się z aktami przemocy na granicy ,,serbsko-kosowskiej”, jak i zamieszkami wewnątrz Serbii - społeczność serbska atakowała m.in. placówki dyplomatyczne państw, które uznały niezależność Kosowa. De facto Serbia utraciła tym sposobem ok. 15\% swojego terytorium. Niepodległość „nowego państwa” uznały zrazu USA, Francja, Niemcy i Wielka Brytania. Kraj, który ze względu na wewnętrzną politykę mniejszościową był sceptycznie nastawiony do niepodległości Kosowa to Hiszpania, co więcej Miguel Angel Moratinos (minister spraw zagranicznych tego kraju) porównał wsparcie międzynarodowe dla Kosowa do inwazji na $\operatorname{Irak}^{27}$. W Polsce nieliczni politycy opowiedzieli się przeciw uznaniu samowładności i całowładności Kosowa - np. W. Cimoszewicz, uznając słusznie, że nie ma takich międzynarodowych podstaw do czynienia tego. Najbardziej sprzeciwiła się temu Federacja Rosyjska, która twierdzi, że rodzi to niebezpieczny precedens i wyłom $\mathrm{w}$ prawie międzynarodowym ${ }^{28}$. Może to zagrozić sytuacji w innych państwach bałkańskich, np. Bośni-Hercegowinie, gdzie o niepodległość może dopominać się Republika Serbska (niektórzy analitycy wskazują na możliwą polityczną pomoc Rosji w tym

27 Przeciw niepodległości Kosowa z podobnych względów opowiedziały się takie państwa, jak: Cypr, Grecja, Rumunia i Słowacja.

28 USA uznaja niepodległość Kosowa. Hiszpania porównuje ja do inwazji na Irak, http://serwisy.gazeta.pl/swiat/1,34229,4938823.html, 29.03.2008, 8 p.m. 
zakresie). Parlament bośniackich Serbów uznał, że jeżeli ten jednostronny akt Kosowa zostanie wsparty uznaniem niepodległości przez dużą część państw na świecie, Republika Serbska także ogłosi niepodległość.

\section{Synteza}

Granica między Czarnogórą a Bośnią-Hercegowiną jest rezultatem różnych czynników. Po pierwsze - religii, po drugie - mieszanki etnicznej, po trzecie - polityki i oczywiście warunków geograficznych. Silniejsze wpływy ortodoksyjnego kościoła w Czarnogórze i Serbii wpłynęły na przetrwanie i ukształtowanie w miarę spójnej populacji tych krajów. Takiej sytuacji nie ma w Bośni-Hercegowinie. Sama Bośnia-Hercegowina (współcześnie) to rezultat uzgodnień politycznych - także na szczeblu międzynarodowym. Przykładem jest obszar tzw. Republiki Serbskiej, która stanowi wschodnią granicę tego kraju. Tak więc Republika Serbska stanowi granicę z Czarnogórą. Przykładowo obecny obszar tej republiki jest nieproporcjonalny do reprezentacji etnicznej (mniejszości serbskiej).

Wpływ polityki, a raczej argument polityki siły jest dobrym przykładem dla ujęć realistycznych w stosunkach międzynarodowych i w geografii politycznej. Dla oceny opisu relacji granicznych dalej ważny jest pryzmat pozytywistyczny i realistyczny w stosunkach międzynarodowych. Potencjał i możliwość użycia siły w polityce zagranicznej to dalej mechanizm oddziaływania na arenie międzynarodowej, chęć władzy jest immanentna zarówno jednostce, jak i takiemu podmiotowi, jak państwo. Daje to możliwość zabezpieczenia własnych interesów i zapewnienia sobie bezpieczeństwa ${ }^{29}$. Skutkiem tego może być określony kształt państw byłej Socjalistycznej Federacyjnej Republiki Jugosławii, a w aspekcie rozważanego problemu granic Bośni i Hercegowiny, jak i Czarnogóry. $Z$ jednej strony jest to rezultat wojny jugosłowiańskiej i porozumień międzynarodowych, a z drugiej - słabej pozycji Serbii, która pozostawiona bez realnego wsparcia na arenie międzynarodowej zostaje rozdrabniana na kolejne podmioty (Czarnogóra - 2006 rok, Kosowo - 2008 rok).

29 V. Kauppi (ed.), International Relations Theory. Realism Pluralism, Globalism, and Beyond, Allyn \& Bacon, Boston 1999, s. 55-88. 


\section{Summary}

The borderline between Montenegro and Bosnia-Heregovina is an outcome of numerous factors: firstly - religion, secondly - ethnic composition, thirdly - politics, and finally - geographical conditions. The stronger influence of the Orthodox Church in Montenegro and Serbia resulted in the survival and relative cohesion of the respective populations of both countries. This has not occurred in Bosnia-Herzgovina. This state is a product of political agreements on the internal and international levels. This may be exemplified by the so-called Serbian Republic that me the eastern frontier of the country. Thus the Serbian Republic constitutes the border with Montenegro. The contemporary territory of the Republic does not proportionately reflect the ethnic composition (Serbian minority). 